\title{
A Labour of Love: The Affective Archives of Popular Music Culture
}

\section{Archives and Records}

\section{NOT FOR REVIEW}

Corresponding Author

Paul Long

Professor of Media and Cultural History

Director, Birmingham Centre for Media and Cultural Research

Room M.344

Birmingham Centre for Media and Cultural Research

Birmingham School of Media

Birmingham City University

Curzon Street

Birmingham

B4 7XG

tel: (044)121-331-5468

\section{Co-authors}

Dr Sarah Baker

Associate Professor

Deputy Head of School (Research)

School of Humanities, Languages and Social Science

Deputy Director I Griffith Centre for Social and Cultural Research

Griffith University

4.15 Arts \& Education building (G30), Gold Coast Campus

2.85 Macrossan building (N16), Nathan Campus

Dr Lauren Istvandity

Industry Research Fellow | Griffith Centre for Social and Cultural Research

Sessional Academic

School of Humanities, Languages, and Social Science | Griffith University

Brisbane, Queensland

Sessional Academic

Queensland Conservatorium Griffith University

Brisbane, Queensland

Jez Collins

Birmingham Music Archive

Centre for Media and Cultural Research

Birmingham City University

Room MP.344

Curzon Street

Birmingham

B4 7XG 


\section{ABSTRACT}

This paper outlines the prodigious field of public history preservation practice prompted by popular music culture, exploring the relationship of affect, history and the archive. Framing this exploration with a concept of cultural justice, it considers the still uncertain place of popular music as a subject of heritage and preservation, assessing the parameters of what counts as an archive and issues of democratisation. It offers a discussion of the archival and affective turns in the humanities as a means of framing the politics of practice focussed on popular music culture. The paper offers empirical evidence of the relational qualities of the popular music archive considered in affective terms. Discussion draws first on evidence from the vernacular practices of communities in what Baker and Collins describe as 'do-ityourself' archives and secondly from 'authorized' collections in established archival institutions. ${ }^{1}$ The paper explores the motivations of popular music archivists and how they articulate the affective dimensions of their work, and how their work qualifies personal and collective commitments and expressions of value and indeed, relations with users. In conclusion, affect is identified as pertinent to wider issues in the relations of archive, archivist and user and the possibilities of historical practice.

Keywords: affect; popular music; public history; DIY archives; authorized archives; cultural justice.

\section{Introduction}

Recent reflections on the nature of the archive have begun to explore its affective dimensions. Affect is that which historian Arlette Farge elegantly describes as a tremor of experience prompted in the encounter with 'the surplus of life that floods the archive'; it is that 'excess of meaning' that provokes users in an intense and unconscious manner in the face of beauty and amazement. ${ }^{2}$ In spite of a general lack of reflexivity about this concept, theorists of the archive have begun to recognize the abiding importance of affect for comprehending its materiality and our relations with it: as builders, keepers, users and perhaps as objects of preservation. As Michelle Caswell, Marika Cifor, and Mario Ramirez suggest, 'affect has always been present as an underlying factor in archival scholarship and practice, but shifting it from a tacit concern to an explicit focus opens it up as a category of analysis and legitimizes it as an area of concern'. ${ }^{3}$ Our focus here is with the presence of affect as an aspect of the archive as manifest in public history practice. We attend in particular to the prodigious field of preservation activity devoted to popular music and how this conjunction tests the boundaries of the archive and its understanding.

Public history was characterized early on by Robert Kelley as 'the employment of historians and the historical method outside of academia'. ${ }^{4}$ It has further served as a label for a wide range of engagements with the past which have proliferated in recent decades and that have in turn challenged the boundaries and nature of historical method. Distinct from the 
generic conventions of scholarly work, public history practice encapsulates historical reenactments, heritage tours, cultural productions such as video games or novels as well as community engagements with memory. ${ }^{5}$ Raphael Samuel has described such non-academic, non-professional encounters with the past as productive indicators of the multifarious ways in which history works as cultural process, a 'social form of knowledge'. ${ }^{6}$ In turn, such practices have impacted on presentations and interpretations of the past and, in the form of the archive, its preservation and indeed the parameters of each category. In the discussion that follows, we consider the archive as a physical site and concept that has become extraordinarily fluid in its definition and understanding, at a confluence of heritage and museology as encompassed by a concept of public history. This fluidity and its challenges are particularly apparent in the variety of ways in which popular music has prompted public history work and the development of archival practices.

Samuel pinpointed the particular role of popular media and representative forms such as film and television in defining public history practice. ${ }^{7}$ By contrast, the role of music in general - and popular music in particular - has been under-researched in relation to this field and poses intriguing ways of thinking about the past, its representation and experience. For instance, popular music has engendered a host of specific and abiding cultural practices, motivated by attachments to songs, artists and moments. Some of this activity emulates that of the historian and archivist as the record, collecting and knowledge of the catalogue and an acquaintance with music history are key for more than just the dedicated aficionado in this culture. ${ }^{8}$ The context for this paper is the prodigious growth in memory, heritage and archival activity focused on popular music cultures. ${ }^{9}$ Such activities are manifest between the officially sanctioned products of the industry, the heritage sector and vernacular practices of consumers. Illustrative examples include: the album reissues industry; ${ }^{10}$ tours by 'heritage' bands performing specific album sets; tourist trails of the Liverpool of the Beatles, ${ }^{11}$ or dedicated museums such as Cleveland's Rock and Roll Hall of Fame. ${ }^{12}$ Here, our focus encompasses those practices described by Baker and Collins who identify several distinct sites of music archival practice which exist on a continuum between on and offline worlds and between the mainstream heritage sector and the vernacular practices of communities. ${ }^{13}$ Their typologies encompass: physical collections housed in physical locations and which are further divided into the categories of 'physical authorised' and 'physical - do-it-yourself'. Then there are digital and online collections which are characterised as 'online - institutional' and 'online - community'.

Here, we first outline the relationship of affect, history and its value for understanding the popular music archive as a mode of public history practice. Of particular interest are issues concerning the parameters of what counts as an archive and indeed the still uncertain place of popular music as a proper subject of collective heritage and preservation. We then turn to empirical evidence of the relational qualities of the popular music archive considered in affective terms. We explore the motivations of popular music archivists and how they articulate the affective dimensions of their work, how it qualifies personal and collective commitments and expressions of value. A relational sense involves also an understanding of archive users and their apprehension of the archive, its being and purpose. Overall, we suggest how this field is inflected by affect and the values it reveals offers a means of 
considering public history practice in terms of cultural justice. This is employed for our purposes as a critical concept that seeks to capture the manifest and implicit impulses of democratised practices, apparent in the formation and content of archives. Cultural justice appositely describes the extension of the meanings and parameters of the archive as a site for preservation and interpretation on the terms of those interlopers who might be allowed to define it for their own purposes as well as for the materials it embraces.

\section{The boundaries of the archive and affect}

A number of scholars have registered an 'archival turn' across the humanities. ${ }^{14}$ This turn has been valuable for bringing into focus the continuities and challenges to the use of the term 'archive' to refer to the official repository of the papers of State. The 'official' archive encompasses also the material cultural heritage and materials of the nation state's past, manifest most obviously in the establishment of national museums, archives, galleries and libraries. A survey of the archival turn then might account for the extension of methods across fields devoted to documenting and preserving the materiality of memory, the past and history. In tandem with the democratising and creative impulse and expression of public history we might also account for how this turn embodies a troubling of traditional boundaries and conventions of the archive and how interested parties understand it. William J. Maher, then President of the Society of American Archivists (1997-8), took issue with what he saw as the misuse and 'bastardization' of the term 'to cover all manner of information gatherings that really are quite clearly not archives' ${ }^{15}$ One site in which traditional boundaries have been tested for instance is in 'a powerful "archival impulse" [...] at play in contemporary visual art', as noted by Louise Boscacci. ${ }^{16}$ Surveying a range of practices that enlist the concept for creative expression, she summarises a number of arguments that suggest that 'within the artistic community, there seems to be little consensus as to what an archive is, how it might be distinguished from other types of artists' collections' ${ }^{17}$ Of particular interest here is her conclusion that in spite of this uncertainty, or perhaps because of it, '[a]II archives are subjective and partial constructions that raise questions about the adequacy, propriety and truthfulness of the accumulated materials and objects'. ${ }^{18}$

As Walter Benjamin wrote, anticipating Samuel's liberal accommodation of what constitutes everyday historical practice, 'collecting is a form of practical memory'. ${ }^{19}$ After scholars such as Flinn and Cook, ${ }^{20}$ one can view the impact on the archive of public history practice and its democratizing thrust, for the ways in which it encapsulates multifarious practices of collecting as well as preservation and presentation. Here one can number the practices of what Geoghegan calls 'enthusiast communities', ${ }^{21}$ or Howard Zinn's 'activist archivists', 22 that are manifest too in the challenge of the digital anarchive. ${ }^{23}$ The online world in particular has seen an efflorescence of sites whose purpose is apparent in titles that claim the designation 'archive' for themselves. The Internet Archive is perhaps the most significant example of this practice. ${ }^{24}$

As Maher's pronouncement suggests, the promiscuous deployment of the title archive, the exploration of it as idea and its ontological status presents particular challenges to 
conventional practice for both archivist and user. For instance, historical geographers like DeSilvey, ${ }^{25}$ Cameron, ${ }^{26}$ De Leeuw, ${ }^{27}$ Ashmore et al, ${ }^{28}$ have worked with the collections of communities and individuals encountered in personal, domestic space that 'challenges assumptions relating to archival conduct and practice and adds to debates surrounding what constitutes an archive'.$^{29}$ Such work has been reflexive about the place of the researcher in affecting the archive and its democratization as idea and accessible site. As a result, Cameron suggests that in these instances archives are then reconceived 'not as selfcontained repositories where one quietly gathers the "facts" but rather as webs of connections and opportunities for dialogue'. ${ }^{30}$ Citing Doreen Massey's definition of places, Cameron positions archives as 'articulated moments in networks of social relations and understandings' ${ }^{31}$ Thus, aspects of the relations and understandings identified by such researchers is that of the affective nature of producing history from the materials of the archive and the way in which such sites themselves produce meaning and experience that impact the researcher and their interpretative faculties.

Alongside the so-called archival turn across the humanities, a turn to affect has also been noted, ${ }^{32}$ which has likewise contributed to a wider dilution of the parameters of disciplinary boundaries. In historiography particularly, this turn is in part due to the impact of experiential qualities of public history activity such as re-enactment, the appeal of reality television or immersion in fictional evocations of the past. ${ }^{33}$ In her summary of history's affective turn, Robinson discusses how the concept of affect is not simply synonymous with emotion. ${ }^{34}$ It involves the corporeal and imaginative realm, both rational and passionate dispositions, and is located between the agency of the researcher and a receptiveness to being acted upon. She describes the affective dimensions of archival research itself, surveying the ways in which it sustains the historian and underwrites knowledge - attuning one to a feeling for the authenticity of records for instance and the manner in which these affirm a sense of truth and the apparent tangibility of the past.

From the perspective of archive theorists, Caswell et al define affect by way of Melissa Gregg and Gregory Seigworth as those 'visceral forces' which inform thought, action and relationship, at one with and in excess of feeling and emotion - between conscious knowing, the semiconscious, nonlinguistic and non-rational. ${ }^{35}$ In total, such ideas acknowledge the human, personal, subjective aspects of the materiality of the archive and its repositories that, as De Leeuw notes have 'political ramifications'. ${ }^{36}$ This observation is pertinent here for the fact that whatever the nature of the affective turn, 'the bodily experience of "doing history" has been rather neglected", ${ }^{37}$ as it has been in archival theory. ${ }^{38}$ Cifor identifies some of the reasons why the affective dimensions of the archive have not been readily addressed in practice and theory. ${ }^{39}$ These include: a modernist sense that archiving practice is scientific, driven by objectivity as well as sense of neutrality, removed from the interests that have authorized and defined repositories in terms of values of detachment and reason. In tandem with this is an approach to the nature of knowledge which is often gendered - that devalues both affect and the everyday, underlining the power and politics of the archive. This is apparent in Maher's discourse in which the 'nonprofessional appropriation' and misuse of the term, whether by scholars, media producers or 'database builders', came to be manifested in the TV show VH1 Archives. 
Maher described the programme as 'little more than some Internet junkie's personal backfiles of top forty tunes', noting it to be no more than an attempt to lend respectability 'to what otherwise might be little more than a personal hobby or collecting fetish' ${ }^{40}$ Thus, a sense of power is important in proceeding, for thinking of the challenge to the boundaries of what constitutes an archive and the nature of what kinds of cultural artefacts and records might be considered to be worthy of preservation and presentation or indeed to be designated as 'archive'.

\section{Popular music and affective cultures of preservation}

That music is imbued with affective powers is apparent in our relations with its sounds and the degree to which it is imbricated in our lives as listeners - whether as casual consumers or dedicated fans. However, the nature of music, and its affective qualities, needs to be located in a wider continuum of relations in order to understand what ends up as the object of archival practice. For instance, Christopher Small's concept of 'musicking' encompasses taking part 'in any capacity, in a musical performance... including a recorded performance, ${ }^{41}$ while the work of Morten Michelson states that music can be conceived as something processual, that extends beyond any one work and structure of sounds, organization, lyric, interpretation and so on. As Michelson, argues, 'there are many different concepts, notions and practices of music circulating in culture at any one time' ${ }^{42}$ As such music can be conceived as an idea that captures songs themselves and their presentational forms - in songs - as well as commodified artefacts and forms that are exchanged - as songs in digital form, vinyl or CD. Likewise, this approach to music encompasses associated cultural intermediations of music culture on film, on TV, and in press coverage for instance.

Our turn to the public institutions and enthusiast communities of interest organised around popular music explores the manner in which they are affectively invested in knowledge and overt feelings about particular places, historical moments and normative ideas of the past constructed by popular music discourse. For instance, one speaks of the 'Dunedin Sound' of New Zealand, 'Swinging Sixties' or 'The New Romantic Era'. Such ideas are often linked to conceptualisations of places and spaces at particular moments in relation to particular sounds such as MerseyBeat, 'Madchester' or Detroit's House Scene. Likewise, one might note the association of musical identities with particular historical periods - American soul music and civil rights in the 1960s or punk's associations with urban crises of the US and UK in the 1970s. This quality and the association of music with experience and ideas of the past can be linked also to music's role in the emotional identity of individuals. This role is derived from encounters with its physical, non-representational qualities as much as overt meanings manifest in lyrics, press reports or artist interviews, informing memory-making and its place in social interaction such as archive building. At the social media community archive site Your Jukebox Remembers :- Hits from the 40s 50s 60s 70s \& 80s, it announces that music 'holds a special memory for those of us who grew up with it. It was music you could Sing along with, music you Fell in Love with, and music you could Dance to' (sic). ${ }^{43}$ One should also note too the deep love of music professed by so many - in general or focused on specific songs, artists, genres and so on - is what underwrites the role of music in individual and collective activity. As Oum Rattanak Oudom, founder of the Cambodian Vintage Music 
Archive puts it: 'I love all of the music from the Golden Era, from the traditional to the modern songs [...] Some years ago, I fell in love with In Yeng, one of the lead male singers in $60 \mathrm{~s}$. He had a wonderful voice which no one could sing like him as similar as of Sinn Sisamouth. He sung mostly slow songs or in a traditional style. His songs haunted my heart and soul'. ${ }^{44}$ In total, such devotion to music in one's life as defined through the records one has accrued (or perhaps lost but whose sound and presence one still recalls), tends to confirm the affective nature of what it means to be a collector. This is to be one of a group that for Walter Benjamin comprise those who hope to be regarded as scholars, connoisseurs, if needs be as owners too, but very rarely as what they above all are: lovers'. ${ }^{45}$

The present authors' research has collectively explored the manner in which collections of popular music material and memory, authorized, DIY, on and offline, offer a challenge to the policing of conventional cultural boundaries and practices of the past as preservation and presentation. For instance, popular music has often proven to be a problematic spectre when presented in traditional galleries, heritage projects, museums and The Archive. There have been criticisms of exhibitions organized around popular music cultural artefacts and collections, questioning their place in the museum. ${ }^{46}$ References to the ephemeral, massproduced and commercial imperatives of pop as product continue to be enlisted in objections to the presence in the museum of materials associated with figures such as Kylie Minogue. ${ }^{47}$ Sunday Times critic Waldemar Januszczak complained of an exhibition at London's V\&A devoted to David Bowie's life and work that it was inappropriate, representing an act of 'colonisation' of a cultural space by commerce. ${ }^{48}$ Even in private galleries with transparently commercial aims, there is suspicion of the cultural value of some exhibitions devoted to pop. Toby Young's critical assessment of an exhibition devoted to the Rolling Stones at the Saatchi Gallery is a good example here. He observed a lack of critical distance about the exhibition's subject and complained about its 'grasping cynicism' for being so obviously an exercise in offering 'rip-off tat for fans to buy'. ${ }^{49}$ There are also critical voices directed at such exhibitions from those who made popular music culture, objecting to its appropriation and appropriateness for preservation and display. For example, Punk.London offers 'a year of events, gigs, films, talks, exhibits and more celebrating 40 years of punk heritage and influence in London', 50 including Punk 1976-78, an exhibition which ran at the British Library. ${ }^{51}$ Endorsed by the former London Mayor Boris Johnson and Queen Elizabeth, this enterprise provoked a vocal reaction from Joe Corré, son of Malcolm MacLaren, the former manager of the Sex Pistols. Having inherited a mass of artefacts related to punk which he claimed were worth $f 5 \mathrm{~m}$, Corré promised to destroy them in symbolic protest: 'Some people are moaning, saying auction it. Fuck off! It's not about that. They're thinking about the money and nothing else. The artefacts represent the ideas - they're in the past and it's the ideas that are important, not the memorabilia'. ${ }^{52}$ The memorabilia of others comprised elements of a related exhibition at the British Library that elicited another critique when Viv Albertine defaced interpretation panels in protest for effectively eliding from this history female artists such as her own band The Slits. ${ }^{53}$

\section{Conceptualizing Cultural Justice}

Examples such as those summarized above suggest how abiding discourses of cultural value 
inflect perceptions of pop's past. Likewise, they suggest how other normative conventions of popular music culture can be anticipated as important here, including its taste-driven judgments and partiality about place, space, social grouping, and collective nostalgia ('music was better then'). Useful here is Sara Ahmed who, echoing John Locke, has argued that pleasure is affective, suggesting that 'We judge something to be good or bad according to how it affects us, whether it gives us pleasure or pain' ${ }^{54}$ Ahmed considers objects in terms of their 'stickiness' for the ways in which affect accrues around them and for the way in which they are assessed and how they play a role in creating happiness or sadness. This is a valuable idea for a consideration of popular music as an object of affection and devotion for individuals and communities: 'This is why the social bond is always rather sensational. Groups cohere around a shared orientation toward some things as being good, treating some things and not others as the cause of delight ${ }^{\prime}{ }^{55}$ Ahmed continues, by way of Bourdieu, to note that pleasure as it is connected with taste is also something that has value $-a$ means by which others make judgments about individuals and groups, marking out whether the objects and practices that give pleasure are deemed worthy of investment. As she suggests: 'affective differentiation is the basis of an essentially moral economy in which moral distinctions of worth are also social distinctions of value'. ${ }^{56}$

Ahmed's insights underline how we can understand the role that affect plays in the political economy of popular music, its heritage practices and the ways in which it is framed in terms of assessments of cultural value. The commercial origins of popular music are at the root of suspicions of its value as cultural expression and as a fit object for study and indeed, for the kinds of attention it engenders amongst audiences. For instance, it is consumers themselves who comprise the enthusiast and activist communities who have articulated the importance of popular music in their lives by their very actions. This reflects the manner in which ordinary people 'make do' with resources available to them, here investing in popular music and materials a sense of cultural value that is not necessarily determined by their exchange value. Lawrence Grossberg has described the 'affective alliances' of music fans and their practices of consumption and association, ${ }^{57}$ while Gilbert Rodman and Cheyanne Vanderdonckt have argued that 'music routinely circulates through the culture in myriad ways that have little (if anything) to do with commerce and capitalism' ${ }^{58}$ They suggest that what is circulated in such activities are not commodities or things understood to be someone's property but instead, 'a set of affectively charged social relationships' ${ }^{59}$ To them a consumer's purchase of music is but one part of a reciprocal set of relations with others that prompt further purchases but also exchange, discussion and the creation of meaning and cultural value. These ideas are also suggestive for thinking of the role of popular music from the past in people's cultural lives of the present, that which they suggest 'cannot readily be reduced to (much less explained by) matters of semantics, semiotics, or ideology: where the central question is "how does it feel?" instead of "what does it mean?"'. 60

This discussion of the importance of the affective dimensions of popular music in relation to its economic and cultural value is a means of comprehending some of the challenges presented in assessing the nature of its uncertain place in authorized archives. The same applies to whether archives operating outside the mainstream sector are afforded any value beyond that ascribed by their communities of interest: amongst scholars or professional 
archivists for instance. Here, Michelle Caswell's description of the 'symbolic annihilation' of particular groups from the record is helpful. ${ }^{61}$ Her work has been focused on counternarratives of marginalized or oppressed groups whose experience and representation is defined in terms devalued by the modernist ethos of the archive as identified by Cifor. ${ }^{62}$ As Cifor summarises, work largely influenced by Ann Cvetkovich, Lauren Berlant and the aforementioned Ahmed, addresses absences, seeking to intervene in the field by 'making visible, complicating and opening up greater possibilities for more just archival practice, scholarship and professionalism'. ${ }^{63}$ Accommodated in this mode of justice is the recognition of affective practice, particularly as represented in Cvetkovich's work An Archive of Feelings that deals with lesbian public cultures. ${ }^{64}$ In the present discussion, there is a role for what appears to be less overtly political and everyday work that is largely motivated by affective pleasures. While the Cambodian Vintage Music Archive mentioned earlier is a pointed exception, popular music archives are not, by and large, born of obvious trauma, yet their nature is nonetheless related to questions of social justice as it pertains to the cultural sphere. Indeed, popular music public history projects as they incorporate a confluence of preservation, presentation and interpretation can usefully be described in terms of a broad concept of cultural justice. This label appositely captures the the manner in which such enterprises draw attention to the kinds of materials and experiences that, in spite of an abidingly uncertain status, are treated as worthy of preservation and which are the proper object of memory and historical thinking.

\section{Manifesting affect: public history, the archival impulse, the archive, archivist and 'user'}

The variety and nature of cultural activities assembled around popular music history makes apparent the human, affective dimensions of archival motivation and enterprise. The extraordinary range of preservation activity within and beyond the mainstream sector, on and offline, evinces the emotional commitments of individuals and groups as well as the investment of experience involved in collecting, preserving and often presenting popular music's material past. With such a wide scope of activities, we draw particular attention here to archival work that spans the amateur-professional spectrum. Beyond abstract or theoretical ideas of the archive, this article broadly understands the archive as a repository of historical materials, including documents, manuscripts, images, recordings and other cultural artefacts and ephemera. ${ }^{65}$ As Manoff and others note, the term 'archive' is often conflated with the concepts of the library and museum. ${ }^{66}$ Indeed, some archives encompassed in our study include the word 'museum' in their title, often doing so in order to enhance public engagement with their collections despite the principal focus being the archiving of material. This is exemplified by the case of the Australian Jazz Museum, formerly known as the Victorian Jazz Archive. As the museum's president explained, the change of name was an attempt 'to try and change the thinking because, "archive", you tend to think of putting it away and storing it, whereas a museum you put it away and store it well but you also exhibit it, get it out there'. ${ }^{67}$

In this section, we first focus on the practices of a number of community and DIY ventures before turning in the next section to consider affective relations of the authorized, institutional archive. Here we draw upon evidence from across public history archival 
practice which has been collected between 2010 to 2015 by the authors as part of a suite of interrelated projects. Baker's research has involved semi-structured interviews with amateur archivists in community-based popular music archives, museums and halls of fame in ten countries as well as interviews with professional archivists and curators in national sound archives, corporate sound archives and large-scale popular music museums and halls of fame. It is in this dataset that we find archives whose title implies museal, rather than archival practices, for example 'Australian Jazz Museum' and 'Museum Rockart'. In Baker's study the focus has been community archives that reside online across multiple platforms, particularly those concerned with the popular music culture of the city of Birmingham, England. A variety of statements and dispositions from the archivists of these studies express vociferous passion as well as the stolidly heartfelt and persistent commitment to recording the existence and impact of a particular band, cultural space, place, genre or musical moment.

The enthusiasm attached to music points to the benign aspects of affect and the motivations of archival enterprises. There is the happiness and the deep pleasure of engagement with music that comes from listening and dancing to it or experiencing live concerts and which impact on individual and collective experience. Affective attachments indicate a 'will to archive', ${ }^{68}$ the motivation to explore and preserve the historical materials and memories of popular music. Above all, such dispositions express a desire for historical material that is not simply a search for narrative, or conclusions arising from evaluations of cause and effect but also an attachment to its ineffable and intangible moments, banal or wondrous artefacts, eyewitness accounts and memories of experiences and feelings themselves. As in one online discussion at the Birmingham Music Archive concerning a longclosed venue, posts discuss how music from the scene engaged with and shared in the past brings back 'great memories' of a better time with one contributor 'wishing we could relive just one more night from start to finish. ${ }^{69}$ While affective qualities are present in most, if not all, archival activities, popular music and its archives are particularly affective. As Baker notes of DIY archives of popular music, such places are 'extensions of musical communities in the present'. ${ }^{70}$ As such the work of the archivist is affect-led, going 'beyond the goal of collection and preservation' and bringing with it 'a range of personal impacts that reach into other areas of the volunteers' lives, with the objects in the collection and their archival practice affecting them deeply'. ${ }^{71}$

Desire and commitment informs the essence of archival practice which is pinpointed by the founder-curator of the Hector Country Music Heritage Museum (New Zealand). He understands his role in the context of a wider set of practices beyond his specific attention to music and which is conducted by a range of 'very interesting people'. Whether their interest lies in planes, olds cars or stones, they are 'eccentric collectors really', for whom 'it's a labour of love'. ${ }^{72}$ This description is the sine qua non of the affective archive, DIY museum or heritage enterprise. Versions of the phrase are repeatedly deployed across the field, ${ }^{73}$ and whether explicit or implicit, love and passion are qualities that impel archival work, collections, display and engagement. 
The directors of the Nederlands Jazz Archief (The Netherlands) underline how the love that informs the labour of the volunteer amateur archivists in their DIY institution translates into an embodied knowledge and commitment. One director notes that volunteers are 'not trained or anything', identifying how their expertise is bound up in the fact that 'They really had a love for the music, a love for the artefacts.' The other director then elaborates on this value, which is 'where a big part of our [the archive's] power comes from because, between everybody who worked at the jazz archive, we knew virtually everything'. ${ }^{74}$ Also untrained in heritage management, the founding members of the Rhode Island Music Hall of Fame (United States) drew attention to the centrality of affect when reflecting on the challenges of their work: 'The pleasures are obvious to us, because we know what we're doing and we know why we're doing it and so it's directly from the heart, from all of us. There are a great deal - many challenges, many of which we don't know yet. We're still learning about them'. ${ }^{75}$

At the South Australian Jazz Archive (Australia), the secretary speaks of the human dimension involved in organising and caring for artefacts in which the affective disposition of volunteers is itself something that transmutes apparently banal material into a thing of wonder. As she states: 'It doesn't look very much but when you open it all up and we astonish ourselves at times'. She recalls rationalising the rejection of the purchase and deployment of a computer system as both too costly and a manifestation of a creeping bureaucratisation of the archive. Ultimately however, faced with her colleagues' rejection of automation she speaks of the value of tacit knowledge and care embodied in the disposition of individuals, that 'I've come around to thinking they're right, it's okay, we can find things. They're safe, they're valued'. ${ }^{76}$

In institutions such as these, in which the majority of preservation work is undertaken by volunteers, although the labour of many might be dedicated out of love, it might also from some angles look akin to a mode of self-exploitation. Asked about the personal rewards that accrue in the role of director and curator of Tónlistarsafn Íslands (Iceland), the institution's founder rejects such a notion, stating that 'I burn for it [...] It's more than a job'. This quality is apparent in his dedication, above and beyond other personal commitments, remarking on the fact that his wife had been working away from home for several months, this was the opportunity to work every weekend, also'. ${ }^{77}$ The sometimes overwhelming nature of individual commitment to such enterprises is expressed by Dirk Houbrechts, founder of the Belgian Pop and Rock Archives. Having handed over his enterprise to The Flanders Music Centre he expressed his appreciation for the 'overwhelmingly massive amount of support, offers for help, and other kind words' he received as a result, commenting that 'I was quitting because I wanted to get myself a life [...] I left the site with the feeling that I had basically wasted a few good years of my life'. ${ }^{78}$

Certainly, the passionate input and commitment of the volunteer poses problems of measurement when the cultural and public good produced is compared to the regular rewards for work. As a founding member of the Rhode Island Music Hall of Fame states: 'I mean it's hard to be a labour of love, no one has made any money'. Voluntarism can make considerable demands on an individual's time, energy and indeed affective commitment to 
music. The founding member of the Hall of Fame continues by describing his input to one exhibition, 'I've been working on this full time since Halloween [...] I'm not saying just me, but it's a lot of work, but we are pretty determined. We've had some people leave the board just because it's too much'. ${ }^{79}$

Preservation of popular music cultures past in this manner affirms its value and importance to the creators of collections: that such material is meaningful, as is their attention to it. This value is underwritten by the pleasure that music has afforded and indeed the happiness accrued in contributing to the archive. Nonetheless, while pleasure and happiness is a core driver, affective motivations are also apparent in the sense of anxiety touched upon in the final comment from the secretary of the South Australian Jazz Archive, above. We would argue then that anxiety and perhaps urgency is also often foundational to the archival impulse. This anxiety can be expressed in questions such as: is this material worth preserving? Is there space in the archive for its preservation? What will happen if it is not preserved? Who else cares about this material now and in the future? In the field of archival practice in general, a sense of anxiety is most clearly articulated in the profession again by Maher who exhibits familiar concerns about the way in which archives are both 'grossly undersupported' (archivists themselves 'remain undercompensated') and underused. More specific to our focus, the Modern Dance Music Research and Archiving Foundation 'seeks to document and celebrate the efforts and accomplishments of dance music pioneers and reflect the current state of dance music and show'. This initiative expresses the desire to generate attention to the genre of dance music in tandem with a fear over what will happen to the material evidence of its value:

The Foundation believes that dance music deserves critical review and study before any other contributors pass into obscurity and before any other historic recordings and significant artefacts are destroyed. Unless historic recordings from the 1970's and 1980's are transferred to a digital medium and the original reel-to-reel recordings are preserved, these recordings will be lost forever. ${ }^{80}$

The motivation for remembering comes from a fear of loss and subsequent forgetting of aspects of popular music's material past. The establishment of the Klaus-Kuhnke-Archiv für Populäre Musik was prompted by terms that speak explicitly to our ascription of motives of cultural justice. It was founded on a recognition that 'vast areas of musical creation were then neglected by both musicology and ethno-musicology', compensating in particular for the manner in which 'the music industry is more interested in the economical exploitation of the music it produces than in its historical and academical assessment ${ }^{\prime}{ }^{81}$

Ultimately, the distinction between commodity and cultural value, between the logic of accounting for an opportunity to make a profit and the investment of the personal, of emotion in the archive, is expressed by the founder of Museum RockArt (The Netherlands) who emphasised: 'I used my own funds to build this place. Now I'm very poor, but very happy.' The founder's happiness is a result of the affective response of users to his collection and the investment of so much of his persona into it: 'When you see the people 
inside, they have fun. That's what we do it for. To make people happy, to share the love of music. [... ] We don't do it for ourselves, we do it for the people'. ${ }^{82}$

The affective motivations behind the construction of music archives, collections, and public history experiences, have a relational objective in that they are aimed at people conceived as potential users, consumers, visitors, audiences or indeed possible community members and contributors. Whether they are members of the community of interest or those who might be brought into the orbit of each collection and its field, anticipation, expectation and anxiety all condition the perspective of curators and their dispositions towards their material and its possible reception. In a pithy consideration of visitors to Hector Country Music Heritage Museum, the founder-curator identifies the relational nature of affective rewards and motivation in his practice. Reiterating that 'It's just been a labour of love', he considers the appeal of that labour and input for others, 'and I think a couple of times I do get a wee bit depressed when no one comes' ${ }^{83}$ Preservation is an end in itself, but it is also a demonstration of the value of this under-regarded cultural expression, which is in need of affirmation in its recognition by users.

\section{Manifesting affect: the authorized archive}

Thus far, these statements of purpose and the insights of the various curators underline Sarah Baker's insights into the affect-led work of volunteers and amateur archivists in what she labels as the DIY institutions of popular music heritage. As indicated above, she has argued that 'archiving affectively is not just about archiving the material of popular music's past but also about what the practice of archiving this material gives to the individual in an emotional sense and, in turn, what the individual gives to the practice ${ }^{8}{ }^{84}$ These DIY institutions are sites in which affect was enabled and enacted in particular ways due to 'the room afforded for the emotional connections that exist between people and things, combined with a communal urge to collect, preserve and archive that is generated by a love of music and performers' ${ }^{85}$ This is not to say that affect does not also operate in significant ways in the mainstream heritage sector. At the National Film and Sound Archive (NFSA) of Australia, archivists often referred in interviews to affective aspects of their practice or the ways in which the mission of the NFSA works to produce affective responses. As a sound archivist at the NFSA explained, the artefacts collected by the repository have the capacity to 'delight': 'I'd like to think that our cultural heritage is really important and can inform and delight, and, so just from that you know it can enrich people's life' ${ }^{86}$

One NFSA archivist reflects on the pleasures involved in the process of building the archive, of sourcing materials and engaging with the human subjects whose stories and interactions provide historical reference points and narratives. Curating Australian film sound recordings and working with the website Screen Online, she recalls with excitement how she researched jingles for Vegemite advertisements and her access to historical practice, a tangible past and the realisation that what she found had value for contemporary popular music economies: 
I actually found this woman in her 80s who sang the original version [...] I talked on the phone with all the members of the family and they were involved and then other people came on board and then there was the film clip and it just was fantastic that there was a window to this whole jingles world. ${ }^{87}$

In recalling this process she evinces the pleasure of such work, expressing the feeling of satisfaction in discovery: 'I loved it. That was just so exciting, and realising that nobody had ever found out before who this singer was' ${ }^{88}$

This NFSA archivist also offers an assessment of the importance of artefacts to those who were part of historical scenes or were consumers of popular music in the past, as well as to new consumers of the past as represented by music and archive collections. She describes how the terms on which this relationship of individual and preserved artefact is conducted is suggestive for turning to consider the user of the archive and their affective response to it, to materials and also to archivists themselves. She states of artefacts that they allow 'people to not only have their own dialogue in their head with their memories but to actually listen and view and in some cases touch materials from particular times that are important to them' ${ }^{89}$ This emphasis on the importance of proximity to visitor experience was also present in interviews with amateur archivists. An opportunity to touch artefacts renders the archival experience all the more affective, for visitors and archivists alike.

While not all professional archivists working in national sound repositories come to their work with a passion for popular music, many of the archivists interviewed at the NFSA articulated intimate relationships and enthusiasms for popular music culture. This ranged from general interests in live music and collecting ('I love going to see live music and, yeah, have a music collection which is a big - of great value to $\mathrm{me}^{90}$ ) to histories of working in the music industry as musicians, festival organisers, band managers and the like. Such a connection allies them with a wider community of music consumers and helps produce an intensity of affect around their archival practice which could be viewed as akin, in some ways, to that experienced by their would-be peers, the amateur archivists in DIY institutions. This is illustrated in one interview with a specialist collector at the NFSA in which his own consumption of music is inflected by his professional disposition as an archivist. Describing his own wide ranging tastes and interests 'even in music that I don't particularly like', he recognizes a need to archive Australian performers in particular for posterity. Here, deeply personal reference points underwrite his sense of music history and its value. He reflects on how individuals like his own parents made home recordings of songs, in his history providing a memento mori to mark his own father's passing and which has also wended its way into the archival record as an example to others of the impulse to preserve. This personal story in turn inflects a wider recognition of the impact of mass produced popular music. As he relates:

I can remember where I was when I first heard the Beatles. I remember, you know, particular songs that have made an impact on my life, and I know that, that's the same for everybody, so, to me that's just the important part of keeping that material and getting that material in, and, um, finding it, and making sure that those, um, 
recordings have a place in, in the history of Australian music, and Australia itself, and makings sure that, you know, they're available for people to come back to. ${ }^{91}$

Whatever the values behind the impulse to archive material and memories, it is salutary to note how the practices of popular music heritage often trespass on the intellectual property of the music and wider entertainment industries. ${ }^{92}$ Compared with the practices of DIY institutions, professionals from the mainstream heritage sector were more conscious of their relations with the music industry and its conventions. One of the NFSA curators has managed to generate some input from industry insiders and in the interview offers some insight into their anxiety as donors of material. Pondering their engagement with the archive and how they decide to deposit their music mementoes and collections, this archivist outlines his interpretation that they are motivated by 'very much a feeling thing'. As he elaborates: individuals in the music business have 'put in a lifetime of work', producing material that has great value for them and which they may wish to see preserved in the knowledge that 'if somebody comes looking for it sometime in the future that they'll be able to get access to it.' Donors invest the value of their material in the values of the archive, 'that we are that trusted place'. Donors are motivated by a sense of posterity's unknowable potential and the historian's summons, that 'they just want to know that their history is safe, and that it's going to be accessible in the future' ${ }^{93}$

Here, the affective dimensions of archiving sometimes rub up against the priorities and cultures of the music business. This is revealed in this curator's approach to companies for donations, his objective 'to see those boxes of discs keep coming in the door'. The invitation to active music business people to contribute to the archive might be viewed by them as a great idea, and the curator invests a lot of emotional labour in them in order to nurture and maintain 'that warm feeling they get from sending the stuff here'. It is a feeling that does not always endure however and some donors become unresponsive to requests as they are simply busy. Yet for this curator, a more convincing reason for their non-cooperation is encapsulated in the choice of 'doing something that makes money versus doing something that gets material to the archive'. Thus, 'we're basically asking people to take some time out of their day to do something that doesn't add to their bottom line' ${ }^{94}$ This again manifests those qualities that we consider to evince a sense of cultural justice and are emphatic of the centrality of affect in the popular music archive. This is work that is highly affective for the curators of the archival material, and the affective qualities of popular music cultures are drawn upon to generate donations of artefacts. The affective relationships outlined in this section hint at the demands of commerce, that the defining materials of popular music at the centre of its historical cultures and the role it has played in personal and collective history are tied to the intellectual property of individuals and corporations. To some degree, and allowing for the varieties of ways in which collections are funded, this relationship also gestures to the under-regarded political economy of the archive in general, which is surely as keen a gatekeeper of cultural inheritance as the archivist.

\section{Conclusions: the archive, affect and cultural justice}


In this paper we have presented attachments to popular music culture as a prompt for public history practice in order to explore the relationship of affect, history and the archive. We have considered the politics of the archive, and the motivations of archival enterprises and archivists themselves. Although the focus of the article is on archives of popular music culture, our arguments about the affective power and attachment of these places of cultural preservation would extend to many other community archives, while the observations of the presence of affect in the work of professional heritage practitioners will likely also resonate for others in the mainstream heritage sector. The significance of this article is in its attention to affect and cultural value in archives of the everyday and in the framing of this exploration by way of the idea of cultural justice. The practices outlined in this article support the point made by Rodman and Vanderdonckt about the generation and ownership of meaning. ${ }^{95}$ The concept of cultural justice captures here the creation of the public value of popular music history, its meanings and affective associations that outstrip the regulation and prohibitions presented by ownership of its defining materials. Likewise, a concept of cultural justice acknowledges the way in which DIY enthusiasts and professionals too, might widen the parameters of the archive and the possibilities of its inclusions and use.

In the relations between official and DIY archive, community and commerce, between collector and user - in which the latter category encompasses the professional historian and consumer of heritage and public history experience - are manifest a variety of interests and impulses. In the particularities of popular music practice which inform an archival impulse and public history activities, affect is paramount. It impels the cultural mission of many in making space for the apparent ephemerality of popular music (and ephemera associated with it) in the archive and for its role in individual and collective histories. In so doing, in the variety of practices in evidence in this paper, questions arise concerning the boundaries of the archive and of its possibilities. These questions do not originate in public history activities around popular music but they do suggest it as a rich site for investigation and further consideration.

In their 10 Theses on the Archive, the Pad.ma collective reflect on some of the implications for archivists and archives presented by creative practitioners for engaging with issues of access, democratization and affect. They suggest that 'Historians have merely interpreted the Archive. The Point however is to Feel it'. ${ }^{96}$ This observation poses interesting challenges for the kinds of history one might make from the kinds of archives presented and discussed here and the affective relations and histories presented by music and associated cultures. To attend to the archive as a site of public history constitutes a potential profanity for professional reason and the rationale for archival practice in recognizing emotive and bodily engagements with materials, the spaces in which they are held, their guardians and users and indeed, the narratives and meanings that may derive from them. In so doing, it foregrounds some of the often under-examined commitments, investments as well as repulsions in and around the archive and indeed the pasts it polices and preserves.

Affective motivations in and around communities of interest in popular music culture thus bring into focus the otherwise obscured attachments, investments and associations of the archive and archivist 'proper'. Some of these involve an avowed 'love' of the archival object 
and a desire for the past it might capture, as well as anxieties about the value, preservation and indeed perception of collections and collecting. That the archivists of music culture discussed here are so transparent about such ideas - as a 'labour of love' - serves to underline how their insights are pertinent to wider issues in the relations of archive, archivist and user. 


\section{Bibliography}

Agnew, Vanessa. "History's affective turn: Historical reenactment and its work in the present." Rethinking History 11, no.3 (2007): 299-312.

Ahmed, Sara. "Happy Objects." Chap. One in The Affect Theory Reader. Durham: Duke University Press, 2010.

Ashmore, Paul, Ruth Craggs, and Hannah Neate. "Working-with: talking and sorting in personal archives." Journal of Historical Geography 38, no.1 (2012): 81-89.

Baker, Sarah. "Affective archiving and collective collecting in do-it-yourself popular music archives and museums." Chap.4 in Preserving Popular Music Heritage. Abingdon: Routledge, 2015.

Baker, Sarah, ed. Preserving Popular Music Heritage: Do-it-yourself, Do-it-together. Abingdon: Routledge, 2015.

Baker, Sarah, and Jez Collins. "Sustaining popular music's material culture in community archives and museums." International Journal of Heritage Studies 21, no. 10 (2015): 983996. http://www.tandfonline.com/doi/full/10.1080/13527258.2015.1041414

Baker, Sarah, and Alison Huber. "'Masters of our own destiny': cultures of preservation at the Victorian Jazz Archive in Melbourne, Australia." Popular Music History 7, no. 3 (2012): 263-282.

Baker, Sarah, and Alison Huber. "Notes towards a typology of the DIY institution: Identifying do-it-yourself places of popular music preservation." European Journal of Cultural Studies 16, no. 5 (2013): 513-530.

Baker, Sarah, Lauren Istvandity, and Raphaël Nowak. "The sound of music heritage: curating popular music in music museums and exhibitions." International Journal of Heritage Studies 22, no. 1 (2016): 70-81.

Benjamin, Walter. The Arcades Project. 1927-40. Edited by Rolf Tiederman. Translated by Howard Eiland and Kevin McLaughlin. Cambridge, MA: Belknap/Harvard UP, 1999.

Benjamin, Walter. Walter Benjamin's Archive: Images, Texts, Signs. Edited by Ursula Marx, Gudrun Schwartz, Michael Schwartz, and Erdmut Wizisla. Translated by Esther Leslie. London: Verso, 2007.

Boscacci, Louise (2015). "The Archive in Contemporary Art: a literature review." International Journal of Liberal Arts and Social Science 3, no.8 (2015): 1-8. (available: http://www.ijlass.org/data/frontlmages/gallery/Vol._3_No._8/1._1-8.pdf. 
Bottomley, Andrew J. "Play It Again: Rock Music Reissues and the Production of the Past for the Present." Popular Music and Society 39, no. 2 (2016): 151-174.

Brocken, Michael. The Twenty-First-Century Legacy of the Beatles: Liverpool and Popular Music Heritage Tourism. Farnham: Ashgate, 2015.

Brusila Johannes, Bruce Johnson, John Richardson eds. Music, Memory and Space. Bristol: Intellect, 2016.

Cameron, Laura J. "Participation, archival activism and learning to learn." Journal of Historical Geography 46 (2014): 99-101.

Caswell, Michelle, Marika Cifor, and Mario H. Ramirez. "’To Suddenly Discover Yourself Existing': Uncovering the Impact of Community Archives 1." The American Archivist 79, no. 1 (2016): 56-81.

Cifor, Marika. "Affecting relations: introducing affect theory to archival discourse." Archival Science 16, no. 1 (2016): 7-31.

Cifor, Marika, and Anne J. Gilliland. "Affect and the archive, archives and their affects: an introduction to the special issue." Archival Science 16, no. 1 (2016): 1-6.

Clough, Patricia Ticineto. "Introduction to The Affective Turn: Theorizing the Social, ed." in The Affective Turn: Theorizing the Social. Durham: Duke University Press, 2007.

Cohen, Sara, Robert Knifton, Marion Leonard, and Les Roberts. Sites of Popular Music Heritage: Memories, Histories, Places. Abingdon: Routledge, 2014.

Collins, Jez, and Paul Long. "Fillin'in any blanks I can: online archival practice and virtual sites of musical memory." Chap. 6 in Sites of Popular Music Heritage. Abingdon: Routledge. 2014.

Cook, Terry. "Evidence, memory, identity, and community: four shifting archival paradigms." Archival Science 13, no. 2-3 (2013): 95-120.

Cvetkovich, Ann. An Archive of Feelings: Trauma, Sexuality, and Lesbian Public Feelings. Durham: Duke University Press, 2003.

de Groot, Jerome. Consuming History: Historians and Heritage in Contemporary Popular Culture. Abingdon: Routledge, 2009.

De Leeuw, Sarah. "Alice through the looking glass: emotion, personal connection, and reading colonial archives along the grain." Journal of Historical Geography 38, no. 3 (2012): 273-281. 
DeSilvey, Caitlin. "Art and archive: memory-work on a Montana homestead." Journal of Historical Geography 33, no. 4 (2007): 878-900.

Downey, Anthony, ed. Dissonant Archives: Contemporary Visual Culture and Competing Narratives in the Middle East. Vol. 1. London: British Academic Press, 2015.

Eichhorn, Kate. The Archival Turn In Feminism. Philadelphia, PA: Temple University Press, 2013.

Ernst, Wolfgang. "Aura and Temporality: The Insistence of the Archive." Barcelona: MACBA, 2013.

Farge, Arlette. The Allure of the Archives. New Haven: Yale University Press, 2013.

Featherstone, Michael. "Archive." Theory, Culture \& Society, 23 no. 2-3, (2006): 591-596.

Flinn, Andrew. "Community Histories, Community Archives: Some Opportunities and Challenges 1." Journal of the Society of Archivists 28, no. 2 (2007): 151-176.

Geoghegan, Hilary. "A new pattern for historical geography: working with enthusiast communities and public history." Journal of Historical Geography 46 (2014): 105-107.

Grossberg, Lawrence. "Another boring day in paradise: rock and roll and the empowerment of everyday life." Popular Music 4 (1984): 225-258.

Gregg, Melissa, and Gregory J. Seigworth, eds. The Affect Theory Reader. Durham: Duke University Press, 2010.

Halley, Jean, and P. Ticineto Clough, eds. The Affective Turn. Theorizing the Social. Durham: Duke University Press, 2007.

Jordanova, Ludmilla J. History in Practice. London: Arnold, 2000.

Kam, Jacqueline. "Success in Failure: The National Centre for Popular Music." Prometheus 22, no. 2 (2004): 169-187.

Kelley, Robert. "Public history: Its origins, nature, and prospects." The Public Historian 1, no.1 (1978): 16-28.

Leggott, James, and Julie Taddeo, eds. Upstairs and Downstairs: British Costume Drama Television from The Forsyte Saga to Downton Abbey. Lanham: Rowman \& Littlefield, 2014.

Leonard, Marion. "Exhibiting popular music: museum audiences, inclusion and social history." Journal of new music Research 39, no. 2 (2010): 171-181. 
Long, Paul and Jez Collins. "Affective memories of music in online heritage practice." In Music, Memory and Space, edited by Johannes Brusila et al. Bristol: Intellect, 2016: 85-101.

Long, Paul. "'Really saying something?' What do we talk about when we talk about popular music heritage, memory, archives and the digital?" In Preserving Popular Music Heritage: Do-it-yourself, Do-it-together, Abingdon: Routledge, 2015.

Long, P., \& Collins, J., (2012). "Mapping the soundscapes of popular music heritage." Chap. 8 in Mapping Cultures. Houndmills: Palgrave Macmillan, 2012.

Maher, William. "Archives, archivists, and society." The American Archivist 61, no. 2 (1998): 252-265.

Manoff, Marlene. "Theories of the Archive from Across the Disciplines." portal: Libraries and the Academy 4, no. 1 (2004): 9-25.

Michelsen, Morten. "Histories and Complexities: Popular Music History Writing and Danish Rock." Popular Music History 1, no. 1 (2004): 19-36.

Pad.ma. "10 Theses on the Archive" Dissonant Archives. London: British Academic Press, 2015

Quinn, Patrick M. "The archivist as activist." Georgia Archive 5, no. 1 (1977): 4.

Reynolds, Simon. Retromania: Pop Culture's addiction to its own past. London: Faber and Faber, 2011.

Robinson, Emily. "Touching the void: Affective history and the impossible." Rethinking History 14, no. 4 (2010): 503-520.

Rodman, Gilbert B., and Cheyanne Vanderdonckt. "Music for nothing or, I want my mp3: The regulation and recirculation of affect." Cultural Studies 20, no. 2-3 (2006): 245-261.

Samuel, Raphael. Theatres of Memory: Past and Present in Contemparary Culture. London: Verso, 1994.

Shepherd, Elizabeth. "Culture and evidence: or what good are the archives? Archives and archivists in twentieth century England." Archival Science 9, no. 3-4 (2009): 173-185.

Small, Christopher. Musicking: The Meanings of Performing and Listening. Middletown, Ct. Wesleyan University Press, 1998.

Steedman, Carolyn. "After the archive." Comparative Critical Studies 8, no. 2-3 (2011): 321340. 
1.Baker and Collins, "Sustaining popular music's material culture", 3

2 Farge, The Allure of the Archives, 31.

3 Caswell et al., "To Suddenly Discover Yourself Existing", 12

4 Kelley, "Public history", 16

5 Samuel, Theatres of Memory; Jordanova, History in Practice; de Groot, Consuming History. 6 Samuel, Theatres of Memory, 8

7 Samuel, Theatres of Memory; see also: de Groot, Consuming History; Leggott and Taddeo, Upstairs and Downstairs.

8 Long, "Really Saying Something?".

9 Cohen et al, Sites of Popular Music Heritage.

10 Bottomley,"Play It Again".

11 Brocken, The Twenty-First-Century Legacy of the Beatles.

12 See: Baker et al., "The sound of music heritage."

13 Baker and Collins, Sustaining popular music's material culture", 3.

14 E.g. Steedman, "After the archive." ; Eichorn, The Archival Turn In Feminism.

15 Maher, "Archives, archivists, and society", 253.

16 Boscacci, "The Archive in Contemporary Art, 3.

17 Ibid.

18 Ibid, 4.

19 Benjamin, The Arcades Project, 205.

20 Flinn, "Community Histories, Community Archives"; Cook, "Evidence, memory, identity, and community."

21 Geoghegan, "A new pattern for historical geography."

22 See: Quinn, "The archivist as activist."

23 Ernst, "Aura and Temporality."

24 https://archive.org/index.php

25 DeSilvey, "Art and archive."

26 Cameron, "Participation, archival activism and learning to learn."

27 De Leeuw, "Alice through the looking glass."

28 Ashmore et al., "Working-with: talking and sorting in personal archives".

$29 \mathrm{lbid}, 89$.

30 Cameron, "Participation, archival activism and learning to learn", 100.

31 Quoted in Ibid, 100

32 Clough, "Introduction to The Affective Turn."

33 Agnew, "History's affective turn."

34 Robinson, "Touching the void."

35 Caswell et al., "To Suddenly Discover Yourself Existing."

36 De Leeuw "Alice through the looking glass", 274.

37 Robinson "Touching the void", 506.

38 Cifor and Gilliland, "Affect and the archive, archives and their affects."

39 Cifor, "Affecting relations."

40 Maher, "Archives, archivists, and society", 254. 
41 Small, Musicking, 26.

42 Michelson, "Histories and Complexities", 25.

43 https://www.facebook.com/Your-Jukebox-Remembers-Hits-from-the-40s-50s-60s-70s80s-368913956480356/home

44 http://aseam.info/?p=3283

45 Benjamin, Walter Benjamin's Archive, 25.

46 See argument in Reynolds, Retromania, 3; Kam, "Success in Failure" 176.

47 See Leonard "Exhibiting popular music" 174.

48 Januszczak, Waldemar. "Loving the alien", The Sunday Times online. Available

< http://www.thesundaytimes.co.uk/sto/culture/arts/Visual_Arts/article1232390.ece> (24

March 2013)

49 Young, T. (2016, April 6). "From squalor to grasping cynicism: How rip-off tat for fans to

buy and recreated sixties bedsit show that new Rolling Stones show is nothing more than an exhibition in money making." Daily Mail Australia. Retrieved from

http://www.dailymail.co.uk/news/article-3525661/From-squalor-grasping-cynicism-rip-tatfans-buy-recreated-sixties-bedsit-new-Rolling-Stones-exhibition-money-making.html

50 http://punk.london

51 http://www.bl.uk/events/punk-1976-78

52 Pattenden, M., (2016, 20 March). “Joe Corré on burning his Sex Pistols collection: 'It's the ideas that are important, not the memorabilia." The Guardian. Retrieved from

https://www.theguardian.com/music/shortcuts/2016/mar/20/joe-corre-burning-sex-

pistols-collection-memorabilia-punk-anniversary

53 http://www.dazeddigital.com/music/article/32077/1/viv-albertine-defaces-punk-

exhibition-for-ignoring-women

${ }^{54}$ Ahmed. "Happy Objects", 31

${ }^{55}$ Ibid, 35.

56 Ibid.

${ }^{57}$ Grossberg, "Another boring day in paradise."

${ }^{58}$ Rodman and Vanderdonckt, "Music for nothing or, I want my mp3", 246.

${ }^{59}$ Ibid, 248.

${ }^{60}$ Ibid 260.

61 Discussed in Caswell et al., "To Suddenly Discover Yourself Existing."

62 Cifor, "Affecting relations."

$63 \mathrm{lbid}, 27$.

64 Cvetkovich An Archive of Feelings.

65 Manoff, "Theories of the Archive", 10.

66 Manoff, "Theories of the Archive."

67 Interview, September 2015.

68 Featherstone, "Archive."

69 http://www.birminghammusicarchive.com/west-end-bar/

70 Baker, "Affective archiving and collective collecting", 59.

$71 \mathrm{lbid}, 46$

72 Interview, February 2014.

73 See: Long and Collins, "Affective memories of music in online heritage practice." 
74 Joint interview, July 2013.

75 Interview, April 2014.

76 Interview, June 2013.

77 Interview, August 2010.

78 http://www.houbi.com/belpop/

79 Interview, April 2014.

80 http://www.dancemusicfound.org/

81 http://www.kkarchiv.de/

82 Interview, September 2011.

83 Interview, February 2014.

84 Baker, "Affective archiving and collective collecting", 46.

85 Ibid, 59.

86 Interview, December 2014.

87 Interview, September 2010.

$88 \mathrm{lbid}$.

89 Interview, September 2010.

90 Interview, August 2010.

91 Interview, August 2010.

92 Collins \& Long, "Fillin'in any blanks I can”; Long, "Really saying something?".

93 Interview, August 2010.

94 Interview, August 2010.

95 Rodman and Vanderdonckt, "Music for nothing."

96 Pad.ma 10 Theses on the Archive, 356 (Capitalisation in original).

\section{Bibliography}

Agnew, Vanessa. "History's affective turn: Historical reenactment and its work in the present." Rethinking History 11, no.3 (2007): 299-312.

Ahmed, Sara. "Happy Objects." Chap. One in The Affect Theory Reader. Durham: Duke University Press, 2010.

Ashmore, Paul, Ruth Craggs, and Hannah Neate. "Working-with: talking and sorting in personal archives." Journal of Historical Geography 38, no.1 (2012): 81-89.

Baker, Sarah. "Affective archiving and collective collecting in do-it-yourself popular music archives and museums." Chap.4 in Preserving Popular Music Heritage. Abingdon: Routledge, 2015.

Baker, Sarah, ed. Preserving Popular Music Heritage: Do-it-yourself, Do-it-together. Abingdon: Routledge, 2015. 
Baker, Sarah, and Jez Collins. "Sustaining popular music's material culture in community archives and museums." International Journal of Heritage Studies 21, no. 10 (2015): 983996. http://www.tandfonline.com/doi/full/10.1080/13527258.2015.1041414

Baker, Sarah, and Alison Huber. "'Masters of our own destiny': cultures of preservation at the Victorian Jazz Archive in Melbourne, Australia." Popular Music History 7, no. 3 (2012): 263-282.

Baker, Sarah, and Alison Huber. "Notes towards a typology of the DIY institution: Identifying do-it-yourself places of popular music preservation." European Journal of Cultural Studies 16, no. 5 (2013): 513-530.

Baker, Sarah, Lauren Istvandity, and Raphaël Nowak. "The sound of music heritage: curating popular music in music museums and exhibitions." International Journal of Heritage Studies 22, no. 1 (2016): 70-81.

Benjamin, Walter. The Arcades Project. 1927-40. Edited by Rolf Tiederman. Translated by Howard Eiland and Kevin McLaughlin. Cambridge, MA: Belknap/Harvard UP, 1999.

Benjamin, Walter. Walter Benjamin's Archive: Images, Texts, Signs. Edited by Ursula Marx, Gudrun Schwartz, Michael Schwartz, and Erdmut Wizisla. Translated by Esther Leslie. London: Verso, 2007.

Boscacci, Louise (2015). "The Archive in Contemporary Art: a literature review." International Journal of Liberal Arts and Social Science 3, no.8 (2015): 1-8. (available: http://www.ijlass.org/data/frontlmages/gallery/Vol._3_No._8/1._1-8.pdf.

Bottomley, Andrew J. "Play It Again: Rock Music Reissues and the Production of the Past for the Present." Popular Music and Society 39, no. 2 (2016): 151-174.

Brocken, Michael. The Twenty-First-Century Legacy of the Beatles: Liverpool and Popular Music Heritage Tourism. Farnham: Ashgate, 2015.

Brusila Johannes, Bruce Johnson, John Richardson eds. Music, Memory and Space. Bristol: Intellect, 2016.

Cameron, Laura J. "Participation, archival activism and learning to learn." Journal of Historical Geography 46 (2014): 99-101.

Caswell, Michelle, Marika Cifor, and Mario H. Ramirez. "'To Suddenly Discover Yourself Existing': Uncovering the Impact of Community Archives 1." The American Archivist 79, no. 1 (2016): 56-81.

Cifor, Marika. "Affecting relations: introducing affect theory to archival discourse." Archival Science 16, no. 1 (2016): 7-31. 
Cifor, Marika, and Anne J. Gilliland. "Affect and the archive, archives and their affects: an introduction to the special issue." Archival Science 16, no. 1 (2016): 1-6.

Clough, Patricia Ticineto. "Introduction to The Affective Turn: Theorizing the Social, ed." in The Affective Turn: Theorizing the Social. Durham: Duke University Press, 2007.

Cohen, Sara, Robert Knifton, Marion Leonard, and Les Roberts. Sites of Popular Music Heritage: Memories, Histories, Places. Abingdon: Routledge, 2014.

Collins, Jez, and Paul Long. "Fillin'in any blanks I can: online archival practice and virtual sites of musical memory." Chap. 6 in Sites of Popular Music Heritage. Abingdon: Routledge. 2014.

Cook, Terry. "Evidence, memory, identity, and community: four shifting archival paradigms." Archival Science 13, no. 2-3 (2013): 95-120.

Cvetkovich, Ann. An Archive of Feelings: Trauma, Sexuality, and Lesbian Public Feelings. Durham: Duke University Press, 2003.

de Groot, Jerome. Consuming History: Historians and Heritage in Contemporary Popular Culture. Abingdon: Routledge, 2009.

De Leeuw, Sarah. "Alice through the looking glass: emotion, personal connection, and reading colonial archives along the grain." Journal of Historical Geography 38, no. 3 (2012): 273-281.

DeSilvey, Caitlin. "Art and archive: memory-work on a Montana homestead." Journal of Historical Geography 33, no. 4 (2007): 878-900.

Downey, Anthony, ed. Dissonant Archives: Contemporary Visual Culture and Competing Narratives in the Middle East. Vol. 1. London: British Academic Press, 2015.

Eichhorn, Kate. The Archival Turn In Feminism. Philadelphia, PA: Temple University Press, 2013.

Ernst, Wolfgang. "Aura and Temporality: The Insistence of the Archive." Barcelona: MACBA, 2013.

Farge, Arlette. The Allure of the Archives. New Haven: Yale University Press, 2013.

Featherstone, Michael. "Archive." Theory, Culture \& Society, 23 no. 2-3, (2006): 591-596. 
Flinn, Andrew. "Community Histories, Community Archives: Some Opportunities and Challenges 1." Journal of the Society of Archivists 28, no. 2 (2007): 151-176.

Geoghegan, Hilary. "A new pattern for historical geography: working with enthusiast communities and public history." Journal of Historical Geography 46 (2014): 105-107.

Grossberg, Lawrence. "Another boring day in paradise: rock and roll and the empowerment of everyday life." Popular Music 4 (1984): 225-258.

Gregg, Melissa, and Gregory J. Seigworth, eds. The Affect Theory Reader. Durham: Duke University Press, 2010.

Halley, Jean, and P. Ticineto Clough, eds. The Affective Turn. Theorizing the Social. Durham: Duke University Press, 2007.

Jordanova, Ludmilla J. History in Practice. London: Arnold, 2000.

Kam, Jacqueline. "Success in Failure: The National Centre for Popular Music." Prometheus 22, no. 2 (2004): 169-187.

Kelley, Robert. "Public history: Its origins, nature, and prospects." The Public Historian (1978): 16-28.

Leggott, James, and Julie Taddeo, eds. Upstairs and Downstairs: British Costume Drama Television from The Forsyte Saga to Downton Abbey. Lanham: Rowman \& Littlefield, 2014.

Leonard, Marion. "Exhibiting popular music: museum audiences, inclusion and social history." Journal of new music Research 39, no. 2 (2010): 171-181.

Long, Paul and Jez Collins. "Affective memories of music in online heritage practice." In Music, Memory and Space, edited by Johannes Brusila et al. Bristol: Intellect, 2016.

Long, Paul. "'Really saying something?' What do we talk about when we talk about popular music heritage, memory, archives and the digital?" In Preserving Popular Music Heritage: Do-it-yourself, Do-it-together, Abingdon: Routledge, 2015.

Long, P., \& Collins, J., (2012). "Mapping the soundscapes of popular music heritage." Chap. 8 in Mapping Cultures. Houndmills: Palgrave Macmillan, 2012.

Maher, William. "Archives, archivists, and society." The American Archivist 61, no. 2 (1998): 252-265.

Manoff, Marlene. "Theories of the Archive from Across the Disciplines." portal: Libraries and the Academy 4, no. 1 (2004): 9-25. 
Michelsen, Morten. "Histories and Complexities: Popular Music History Writing and Danish Rock." Popular Music History 1, no. 1 (2004).

Pad.ma. "10 Theses on the Archive" Dissonant Archives. London: British Academic Press, 2015

https://www.theguardian.com/music/shortcuts/2016/mar/20/joe-corre-burning-sexpistols-collection-memorabilia-punk-anniversary

Quinn, Patrick M. "The archivist as activist." Georgia Archive 5, no. 1 (1977): 4.

Reynolds, Simon. Retromania: Pop Culture's addiction to its own past. London: Faber and Faber, 2011.

Robinson, Emily. "Touching the void: Affective history and the impossible." Rethinking History 14, no. 4 (2010): 503-520.

Rodman, Gilbert B., and Cheyanne Vanderdonckt. "Music for nothing or, I want my mp3: The regulation and recirculation of affect." Cultural Studies 20, no. 2-3 (2006): 245-261.

Samuel, Raphael. Theatres of Memory: Past and Present in Contemparary Culture. London: Verso, 1994.

Shepherd, Elizabeth. "Culture and evidence: or what good are the archives? Archives and archivists in twentieth century England." Archival Science 9, no. 3-4 (2009): 173-185.

Small, Christopher. Musicking: The Meanings of Performing and Listening. Middletown, Ct. Wesleyan University Press, 1998.

Steedman, Carolyn. "After the archive." Comparative Critical Studies 8, no. 2-3 (2011): 321340. 